DOI https://doi.org/10.30525/978-9934-588-81-5-1.29

\title{
ОСОБЛИВОСТІ РЕГУЛЯЦІЇ КАЛЬЦІСВОГО ГОМЕОСТАЗУ У ШКОЛЯРІВ, ХВОРИХ НА БРОНХІАЛЬНУ АСТМУ, З УРАХУВАННЯМ БАЗИСНОЇ ТЕРАПІЇ ІНГАЛЯЦЙНИМИ ГЛЮКОКОРТИКОСТЕРОЇДНИМИ ПРЕПАРАТАМИ
}

\author{
Колоскова О. К. \\ доктор медичних наук, \\ професор кафедри педіатрї та дитячих інфекиійних хвороб \\ Вищий державний навчальний заклад Украйни \\ «Буковинський державний медичний університет» \\ Буринюк-Глов'як Х. П. \\ аспірант кафедри педіатрії та дитячих інфекиійних хвороб \\ Вищий державний навчальний заклад Украӥни \\ «Буковинський державний медичний університет» \\ м. Чернівиі, Україна
}

Вступ. Всупереч розробленим науково обгрунтованим рекомендаціям і настановам з лікування і профілактики бронхіальної астми (БА), доступності препаратів базисного лікування та пристроїв для інгаляційної доставки, контроль дитячої бронхіальної астми залишається далеким від досконалості. Інгаляційна терапія з використанням препаратів глюккортикостероїдів (ГКС) залишається наріжним каменем лікування БА у дитячому віці [1], а застереження щодо побічних ефектів, які викликаються системними впливами кортикостероїдів, наразі зменшилися, проте не зникли повністю за використання інгаляційного методу доставки препаратів [2, с. 12]. Так, відомо, що ГКС несприятливо впливають на функцію та виживання остеобластів і остеоцитів , а при збільшенні виживання остеокластів спричиняють метаболічні порушення у кістках [3, с. 85]. Хоча взаємозв'язки між використанням ІГКС та мінеральною щільністю кісткової тканини у дітей залежать від низки інших модифікуючих чинників [4, с. 19]. Проте існують припущення , що тривале застосування високих доз ІГКС при БА у дітей призводить до зменшення кісткової маси у періоді препубертату [5, с. 22-6, с. 88], а ризик невертебральних переломів, ймовірно, зростав при збільшенні добової дози ІГКС, хоча не виключеною $є$ роль власне самого хронічного респіраторного захворювання [7, с. 67]. В іншому дослідженні за участі хворих дітей, які тривалий час отримували високі дози флутиказонупропіонату 
(771,2 мкг / доба), не показано значних порушень кісткового метаболізму та щільності кісток порівняно з контролем $[8$, с. 85].

Таким чином, питання обміну та регуляції кальцію при БА залишаються остаточно нерозв'язаними, а результати досліджень суперечливими.

Мета роботи. На підставі особливостей регуляції обміну кальцію за вмістом у сироватці паратгормону, дослідити перебіг бронхіальної астми у школярів з урахуванням добової дози інгаляційних глюкокортикостероїдів.

Матеріал і методи. Дітей шкільного віку, хворих на персистуючу БА (пБА), залежно від вмісту в сироватці паратгормону, розподілено на дві групи порівняння. Першу (I) групу сформували 30 хворих, piвень паратгормону (ПТГ) у сироватці крові яких перевищував 10,0 пг/мл, а другу (II) - 35 дітей, хворих на пБА, з нижчими значеннями функції прищитових залоз. Вивчення клінічно-інструментальних особливостей перебігу астми проводилося з урахуванням того, що нормою для вмісту ПТГ у сироватці є значення у межах коридору 10,4-66,5 пг/мл (за даними виробника).

За основними клінічними ознаками групи були зіставлюваними. Так, середній вік представників I групи становив $(10,54 \pm 0,52)$ року, а II групи - $(10,28 \pm 0,6)$ року, при цьому тривалість захворювання відповідно сягала $4,76 \pm 0,78$ та $3,81 \pm 0,57$ року $(\mathrm{Pt}>0,05)$. Хлопчиків у I групі було незначно більше $(69,2$ проти 50,0\%), а дівчат відповідно дещо менше (30,7 проти 50,0\%) (в усіх випадках Р $\varphi>0,05)$.

Результати і обговорення.Нами не виявлено закономірних змін вмісту ПТГ у сироватці крові у хворих залежно від дозового навантаження препаратами іГКС, за винятком діапазону високих доз (табл. 1)

Таблиця 1

Розподіл добових доз ІГКС у групах порівняння $(\mathbf{P} \pm \mathbf{m})$

\begin{tabular}{|c|c|c|c|}
\hline $\begin{array}{c}\text { Характеристика доз IГКС } \\
\text { у базисному лікуванні }\end{array}$ & $\begin{array}{c}\text { I група } \\
\text { (n=30) }\end{array}$ & $\begin{array}{c}\text { II група } \\
\text { (n=35) }\end{array}$ & $\mathbf{P} \boldsymbol{\varphi}$ \\
\hline Низькі дози ІГКС & 15,4 & 31,3 & $>0.05$ \\
\hline Середні дози ІГКС & 34,6 & 46,9 & $>0.05$ \\
\hline Високі дози ІГКС & 50,0 & 21,8 & $<0.05$ \\
\hline
\end{tabular}

Отже, за низького вмісту ПТГ у сироватці крові діти вірогідно частіше отримували терапію низькими та середніми дозами іГКС: ВШ = 3,6 (95\%ДІ 1,9-6,6), ВР = 2,0 (95\%ДІ 1,6-2,5), АР =0,31. Мабуть, високі дози сприяли певною мірою розвитку остеопорозу і ви- 
миванню кальцію з кісток, що у свою чергу, стимулювало синтез паратиреоїдного гормону.

Всупереч цьому, ми не отримали статистично значущих розбіжностей вмісту кальцію сироватки у хворих клінічних груп порівняння. Так,

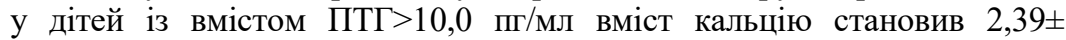
0,01 ммоль/л (мінімальне значення 2,28, максимальне 2,44 ммоль/л). У представників II групи ці маркери становили 2,38 $\pm 0,008$ ммоль/л (мінімальне 2,32, максимальне 2,42 ммоль/л) (Pt>0,05).

Не впливала на рівень сироваткового кальцію і контрольованість БА: у хворих із контрольованою пБА кальцій сироватки у середньому становив 2,38 $\pm 0,04$ ммоль/л, а за неконтрольованого перебігу $2,41 \pm 0,01$ ммоль/л $(\mathrm{Pt}>0,05)$.

Особливості контролю пБА у дітей підгруп порівняння наведені табл. 2 .

Таблиця 2

Порівняльна оцінка контролю пБА в міжприступному періоді у дітей клінічних груп порівняння $(\mathbf{M} \pm \mathbf{m})$

\begin{tabular}{|c|c|c|c|c|}
\hline \multirow{2}{*}{\multicolumn{2}{|c|}{$\begin{array}{c}\text { Показники контролю } \\
\text { бронхіальної астми (в балах) }\end{array}$}} & \multicolumn{2}{|c|}{ Клінічні групи } & \multirow{3}{*}{$\frac{\mathbf{P t}}{>0,05}$} \\
\hline & & \multirow{2}{*}{$\begin{array}{c}\mathbf{I n}=\mathbf{3 0}) \\
2,39 \pm 0,21\end{array}$} & \multirow{2}{*}{$\begin{array}{c}\mathbf{I I}(\mathbf{n}=\mathbf{3 5}) \\
2,57 \pm 0,14\end{array}$} & \\
\hline 菣 & $\begin{array}{c}\text { Симптоми захворювання } \\
\text { денні }\end{array}$ & & & \\
\hline \multirow{7}{*}{ 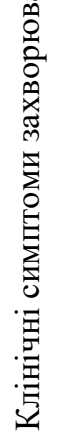 } & $\begin{array}{c}\text { Симптоми захворювання } \\
\text { нічні } \\
\end{array}$ & $1,47 \pm 0,15$ & $1,63 \pm 0,14$ & $>0,05$ \\
\hline & $\beta 2$-агоністи за потребою & $1,67 \pm 0,15$ & $1,77 \pm 0,16$ & $>0,05$ \\
\hline & $\begin{array}{c}\text { Обмеження фізичної } \\
\text { активності }\end{array}$ & $2,53 \pm 0,14$ & $2,35 \pm 0,14$ & $>0,05$ \\
\hline & Частота госпіталізацій & $1,9 \pm 0,07$ & $1,85 \pm 0,07$ & $>0,05$ \\
\hline & Частота загострень & $0,89 \pm 0,15$ & $0,86 \pm 0,12$ & $>0,05$ \\
\hline & $\begin{array}{c}\text { Позаплановізвернення } \\
\text { до лікаря } \\
\end{array}$ & $2,5 \pm 0,13$ & $2,57 \pm 0,1$ & $>0,05$ \\
\hline & Сума балів & $13,11 \pm 0,95$ & $13,74 \pm 0,63$ & $>0,05$ \\
\hline
\end{tabular}

Таким чином, попри розбіжності за тяжкістю і дозовим навантаженням ІГКС, пБА у дітей клінічних груп порівняння контролювалася 3 однаковою ефективністю. Установлені кореляційні статистичнозначимі зв'язки вмісту паратгормону в сироватці із тривалістю застосування системних ГКС під час нападів БА $(\mathrm{R}=0,72)$, що підкреслювало вплив даних препаратів на фосфорно-кальцієвий обмін, що супроводжується остеопорозом і стимуляцією викиду ПТГ. 
У табл. 3 наведені порівняльні показники спірографічного обстеження та провокаційної проби з фізнавантаженням у дітей клінічних підгруп порівняння.

Таблиця 3

\section{Показники спірографічного обстеження у дітей груп порівняння (M $\pm \mathbf{m})$}

\begin{tabular}{|c|c|c|c|}
\hline Спірографічний показник & I група & II група & $\mathbf{P t}$ \\
\hline $\mathrm{FEV}_{1}(\%)$ & $88,15 \pm 3,77$ & $81,66 \pm 3,19$ & $>0,05$ \\
\hline Життєва ємність легень(\%) & $93,81 \pm 3,87$ & $90,91 \pm 2,72$ & $>0,05$ \\
\hline Індекс Тіфно & $0,97 \pm 0,03$ & $0,86 \pm 0,04$ & $=0,05$ \\
\hline Індекс бронхоспазму $\left(\mathrm{FEV}_{1,} \%\right)$ & $8,36 \pm 2,19$ & $12,47 \pm 2,90$ & $>0,05$ \\
\hline Індекс бронходиляції(FEV $1, \%)$ & $14,07 \pm 2,45$ & $14,56 \pm 3,61$ & $>0,05$ \\
\hline $\begin{array}{c}\text { Показник лабільності бронхів } \\
\left(\mathrm{FEV}_{1} \%\right)\end{array}$ & $22,31 \pm 3,07$ & $22,32 \pm 4,78$ & $>0,05$ \\
\hline
\end{tabular}

Отже, у хворих зі зниженням функції прищитових залоз і меншим за норму вмістом у сироватці ПТГ відмічене виразніше порушення бронхіальної прохідності у періоді клінічного благополуччя, ніж в однолітків зі збереженою функціональною здатністю прищитових залоз: ВШ = 5,4 (95\%ДІ 2,0 - 14,4), ВР = 1,8 (95\%ДІ 0,7 - 4,5), АР = 0,37. Мабуть, у пацієнтів зі зменшеним вмістом ПТГ у сироватці крові, слід переглянути тактику базисного лікування з позицій «сходинка вгору».

\section{Література:}

1. Global Initiative for Asthma. Pocket Guide for Asthma Management and Prevention. Updated April 2015. Availableat: http://ginasthma.org/wpcontent/uploads/2016/01/GINA_Pocket_2015.pdf. Accessed 30 January, 2016.

2. de Benedictis FM, Bush A. Corticosteroids in respiratory diseases in children. Am J Respir Crit Care Med. 2012; P. 12-23.

3. Chee C., Sellahewa L., Pappachan J.M. Inhaled corticosteroids and bone health. Open Respir Med J. 2014; P. 85-92.

4. Buehring B., Viswanathan R., Binkley N., Busse W. Glucocorticoid-inducedosteoporosis: anupdate on effects and management. J Allergy Clin Immunol. 2013; P. 19-30.

5. Boot A.M., de Jongste J.C., Verberne A.A., Pols H.A., de Muinck Keizer-Schrama SM Bone mineral density and bone metabolism of prepubertal children with Hossnyetal. World Allergy Organization Journal 1(2016) 9:26 Page 22 of 24 asthma after long-term treatment with in haled corticosteroids. Pediatr Pulmonol. 1997; P. 79-84. 
6. Allen H.D., Thong I.G., Clifton-Bligh P., Holmes S., Nery L., Wilson K.B. Effects of high-dose inhaled corticosteroids on bone metabolism in prepubertal children with asthma. Pediatr Pulmonol. 2000; P. 88-93.

7. Harris M., Hauser S., Nguyen T.V., Kelly P.J., Rodda C., Morton J., Freezer N., Strauss B.J., Eisman J.A., Walker J.L. Bone mineral density in prepubertal asthmatics receiving corticosteroid treatment. J. Paediatr Child Health. 2001; 37:67-71.

8. Van Staa T.P., Bishop N., Leufkens H.G., Cooper C. Are inhaled corticosteroids associated with an increased risk of fracture in children? Osteoporos Int. 2004; P. 85-91.

DOI https://doi.org/10.30525/978-9934-588-81-5-1.30

\title{
ВИЗНАЧЕННЯ ЕФЕКТИВНОСТІ ЛОКАЛЬНОЇ ДІЇ ПЕРЕПАРАТУ НА ОСНОВІ БЕНЗИДАМІНУ ГІДРОХЛОРИД \\ У ПІСЛЯОПЕРАЦІЙНОМУ ПЕРІОДІ У ПАЦІЕНТІВ З ХРОНІЧНИМИ ДЕСТРУКТИВНИМИ ПЕРІАПІКАЛЬНИМИ ПРОЦЕСАМИ
}

\begin{abstract}
Корніснко М. М.
кандидат медичних наук,

асистент кафедри хірургічної стоматологї та щелепно-лицевої хірургії Львівський національний медичний університет імені Данила Галищького

Мінько Л. Ю.

кандидат медичних наук, доцент, доцент кафедри терапевтичної стоматології факультету післядипломної освіти

Львівський національний медичний університет імені Данила Галицького м. Львів, Україна

Проблема профілактики ускладнень залежить від тактики післяопераційного лікування, яка незважаючи на успіхи в ії розробці, вимагає певних вдосконалень. Дані літератури вказують, що навіть найбільш ефективні сучасні фармакологічні препарати та схеми лікування втрачають свій вплив та потребують заміни і вдосконалення $[1,2,3,4,5]$.

Внаслідок операційної травми виникає порушення кровообігу у післяопераційних тканинах, змінюються біохімічні показники ротової
\end{abstract}

